\title{
BEYOND PROPAGANDA: POSITIONING THOMAS PAINE'S COMMON SENSE IN THE \\ LITERATURE OF REVOLUTION
}

\section{Dallin Higham}

\begin{abstract}
:
In this article, I seek to define the status and role of Thomas Paine's Common Sense as a historical document. I argue that although Paine's influential pamphlet offers no original ideas and seems simply to reinforce existing trends, its layered text transcends the regurgitation of propaganda and extends to literary achievement in its reflection of social and economic conditions, its deliberate narrative style, and its usage of literary devices and culture references grounded in historical context. Consequently, my methodology is necessarily focused through literary discourse to achieve historical understanding of this key document from the American Revolution.
\end{abstract}


As tensions between England and America rose in the mid 1770s, Thomas Paine anonymously published a pamphlet addressed "to the inhabitants of America," emphatically urging violent separation from the British empire. Titled Common Sense, this pamphlet has endured in the discourse of American revolutionary history, and provides unique insight into the dramatic escalation of hostilities between two formerly cooperative peoples. Considering the contemporary social climate, ripe with political and philosophical debate, I assert that Common Sense proposes few original ideas; however, I further argue it is equally inaccurate to categorize it as simple propaganda reinforcing existing trends. Instead, Paine's pamphlet is an impressive literary achievement tailored to social, political, and economic conditions, and offered both lasting influences and unheeded suggestions to the American revolution.

Long before Paine published Common Sense, various socio-economic influences had slowly corrupted the relations between England and her American colony during the century between 1660 to 1760 — creating the social climate on which Paine would later capitalize in his pamphlet. Jack Greene catalogues several of these influences in his essay, “An Uneasy Connection: An Analysis of the Preconditions of the American Revolution." He notes that Americans were increasingly "inclusivist, rather than exclusivist," ${ }^{1}$ which translated to a relatively large percentage of enfranchised male citizens, compared to other contemporary regimes. Thus, Americans had already begun striving toward the ideal of equality, which would later become a founding pillar in Paine's arguments for separation from Britain.

Greene further observes the growing number of men with technical skills, particularly in law, trade, and finance. He argues these skills were not only crucial in resisting the British, but that they also helped to "raise levels of literacy and education within the colonies, [and] to widen

\footnotetext{
${ }^{1}$ Jack Greene, “An Uneasy Connection: An Analysis of the Preconditions of the American Revolution.” Essays on the American revolution, ed. Stephen Kurtz and James Hudson (The University of North Carolina Press, 1973 ), 38.
} 
their range of perception and imagination."”2 These rising levels of literacy and expanding awareness of politics in the American population likely contributed greatly to the success of Common Sense, given the abundance of people able to read and understand it. Greene also addresses the growing American economy: "The wealth of the colonies had become sufficient to give them a potential for economic and military resistance, while the sheer vastness of all the continental colonies, taken together, constituted a formidable obstacle to suppressing any largescale or broadly diffused movement of resistance."3 Such economic stability later strengthened Paine's call to arms, as he explicitly outlined America's contemporary military potential compared to the capacities of the British Navy. Thus, changes in the social and economic climate of America throughout the century prior to the publishing of Common Sense gradually conditioned Americans to the kinds of ideas Paine later proposed in his pamphlet.

In addition to experiencing changing socio-economic conditions, Americans held implicit assumptions about imperial power which were systematically challenged by the British, fueling greater desire for separation. Later in his essay, Greene identifies these assumptions as, first, an "expectation that the imperial government would place as few impediments as possible in the way of the colonists' free pursuit of their own social and economic interests." ${ }^{4}$ Secondly, he outlines the assumption "that the imperial government would not interfere with the capacity of the colonists as individuals to maintain their personal autonomy." 5 Operating under these expectations, American colonists had no pressing motivation to revolt against the British; however, beginning in 1748 and lasting until 1756, the British Board of Trade under George Dunk, earl of Halifax, embarked on a reforms program to solidify imperial authority in the

\footnotetext{
${ }^{2}$ Greene, "An Uneasy Connection." 39-40.

${ }^{3}$ Greene, "An Uneasy Connection." 40.

${ }^{4}$ Greene, "An Uneasy Connection." 56.

${ }^{5}$ Greene, “An Uneasy Connection." 59.
} 
colonies. Halifax implemented a packet-boat system to increase communication with the colonies and mandated several legal and political restraints, including a revision of all local laws to adhere more strictly to British law, and the suppression of any lower houses that appeared to encroach on the prerogatives of the crown. ${ }^{6}$ England continued acting against American assumptions of imperial authority, tightening control over the colonies, which culminated in the 1774 imperial restrictions Americans distastefully referred to as the "Intolerable Acts."

This British response to the destruction of tea shipments by the Boston Tea Party directly challenged American assumptions of imperial power in two ways. First, the British restricted American economic and social freedom through the Boston Port Act and the Quartering Act. While the Boston Port Act effectively shut down the Boston port and curtailed economic trade in Boston, the Quartering Act forced Americans to house British soldiers in barracks provided by the colonies, imposing soldiers on an American social setting, which colonists deemed unnecessary. The Massachusetts Government Act and the Administration of Justice Act further compromised American sense of personal autonomy, since they unilaterally took away the Massachusetts charter and stifled colonists' freedom to fully execute justice. Through one sweep of laws passed in 1774, the British uprooted American assumptions of Imperial power, stirring dissatisfaction in colonial relationship with the British. Thus, Paine clearly did not present radically new ideas, or engender unprecedented emotions; rather, he published in an atmosphere in which the seeds of revolt had already been sown.

Although Paine manipulated existing sentiment, his pamphlet nevertheless fomented a zeal for revolution unparalleled among the fruits of the contemporary American press. The

\footnotetext{
${ }^{6}$ Greene, “An Uneasy Connection.” 5.
} 
opinions of the most notable leaders of the American revolution drastically changed as they met the arguments in Paine's common sense. John Holmes highlights this transformation:

Even George Washington argued as late as May, 1775, that [ideas pertaining to revolution] were "wicked," and that reconciliation was still possible. In June of the same year, Thomas Jefferson expressed a hope to remain with England. Half a year later, however, both Washington and Jefferson prepared to risk everything to wage war against British rule, and both cited a small pamphlet as changing the minds of their countryfolk, if not their own: Thomas Paine's fiftysix-page Common Sense (1776), first published anonymously. ${ }^{7}$

Years after the revolution, Jefferson praised Paine's writing ability, hinting at the influence the latter had on the former: "No writer has exceeded Paine in ease and familiarity of style, in perspicuity of expression, happiness of elucidation, and in simple and unassuming language." 8 Perhaps more significantly than encouraging revolutionary leaders, Common Sense also heavily swayed public opinion throughout the colonies. The first and second editions sold out in a matter of days, and by the end of three months, Paine had sold a record 120,000 copies. ${ }^{9}$ Such unprecedented popularity points to the resonance of the pamphlet among an increasingly literate American population, which had been gradually orienting itself toward the bold ideas presented in Common Sense.

Paine achieved this galvanizing influence through impressive writing and literary strategies, effectively tailoring the first and ensuing editions of his pamphlet to the sensibilities of his readers. Edward Larkin notes, for example, the impact of Paine's accessible writing style,

\footnotetext{
7 John Holmes, "Paine Publishes Common Sense." Salem Press Encyclopedia (2013).

${ }^{8}$ Thomas Jefferson to Francis Eppes, 19 January 1821. The Political Writings of Thomas Jefferson, ed. Merrill Peterson (Thomas Jefferson Memorial Foundation, 1993), 1451.

${ }^{9}$ Holmes, "Paine Publishes Common Sense."
} 
as compared to more formal writing: "By insisting that truth is by its nature simple and universal, Paine both manipulates and politically enfranchises a new popular audience by presenting what are actually complex and rhetorically sophisticated arguments as simple facts." ${ }^{10}$ This appeal to ordinary reason and common sense is clear throughout Paine's aptly titled pamphlet. He states this drive for simplicity forthright: "In the following pages, I offer nothing more than simple facts, plain arguments, and common sense." 11 This simple and succinct sentence clearly outlines the accessible style of his writing for his readers, and focuses their attention on his arguments, rather than on his own sophistication. In fact, he criticizes overly complicated writing, pointing out, for example, that the "English constitution is so exceedingly complex." 12 Reminding his readers of the English constitution's complexity, Paine provides stark contrast to his own pamphlet, highlighting its accessibility and making it more appealing to the public.

In addition to using everyday language, Paine makes his pamphlet accessible to the common American colonist through pointed imagery. For example, to illustrate Britain's overbearing influence on the American colonies, he writes: "though we have been wise enough to shut and lock a door against absolute monarchy, we at the same time have been foolish enough to put the Crown in possession of the key."13 This specific and relatable image draws Paine's argument clearly in the minds of his readers, facilitating emotional mobilization in support of his ideas. He further appeals to the common labourer by illustrating the idleness of the monarchy, who, "after sauntering away their lives without pleasure to themselves or advantage to the nation, withdraw from the scene and leave their successors to tread the same idle ground." 14 To

\footnotetext{
${ }^{10}$ Edward Larkin, Thomas Paine and the Literature of Revolution (Cambridge University Press, 2005).

${ }^{11}$ Paine, Common Sense. (London: Printed for H.G. Symonds, 1792), 12.

12 Paine, Common Sense, 5.

${ }^{13}$ Paine, Common Sense, 6.

${ }^{14}$ Paine, Common Sense, 11.
} 
emphasize this point, he adds gluttony to idleness, lamenting that the monarchy has "swallowed up the power, and eaten out the virtue of the House of Commons (the republican part in the constitution)." 15 This unflattering imagery of the British monarchy powerfully resonated with readers, especially since Paine strategically timed the publication of his pamphlet to appear alongside a provocative speech by King George, "denouncing as treasonous American complaints about not being allowed to choose governors and being taxed without representation," and adding that "the complainers needed to be silenced by force." 16 Paine compares this speech to his pamphlet in its second edition, asserting that the "bloody mindedness of the one shows the necessity of pursuing the doctrine of the other." ${ }^{17}$ He therefore strengthens the effect of his imagery of monarchy by exposing the stark brutality of King George. Thus, using creative diction to illustrate the oppression of the Crown, Paine more readily garners support from the working public, whose values and morals stand firmly against the images of the British monarchy he sketches.

Furthermore, Paine includes references both to popular and academic culture, to appeal to a wider range of readers. Early in his pamphlet, Paine refers to hereditary rule as "Mahometlike." 18 Using the French translation of Muhammed, Paine arguably alludes to Voltaire's play with the same name; this connection seems reasonable since the play discusses self-serving manipulation, as Paine does in Common Sense. It is likely (though not certain) that Voltaire's popular play was presented in American theatres, given the heavy influence of European theatre in America. ${ }^{19}$ Thus, this cultural reference to Mahomet by Voltaire would have represented an

\footnotetext{
15 Paine, Common Sense, 11 (emphasis added).

${ }^{16}$ Holmes, "Paine Publishes Common Sense."

${ }^{17}$ Paine, Common Sense, 28.

${ }^{18}$ Paine, Common Sense, 9.

19 “A History of the American Theatre.” American Railroad Journal (November 1832), 715.
} 
appeal to commoners through $18^{\text {th }}$ century entertainment. Additionally, Paine targets the more educated elites, in a comprehensive attempt to rally the entire American population in favour of separation from the British Empire. Later in his pamphlet, he cites John Milton: "Never can true reconcilement grow, where wounds of hate have pierced so deep." ${ }^{20}$ Relying on the intellectual support of an internationally recognized writer and polemicist, Paine not only engages common readers, who might have known of and respected Milton, but he also establishes greater credibility of his arguments for the more educated readers who might have studied Milton's writing and condemnations of government over-reaching. Through these and other references to entertainment and literature, Paine appeals not only to the common reader, but also to the more educated leaders of the revolution, thereby amassing greater support for his arguments.

Though Paine's masterfully implemented writing strategies manipulated popular opinion in favour of his separatist arguments, he failed to secure support for several other key ideas presented in his pamphlet. For example, one of Paine's central themes hinged on the notion of universal equality, including the emancipation of slaves. Paine himself was staunchly opposed to slavery, ${ }^{21}$ and included this philosophy in his pamphlet, arguing that slavery is the consequence of monarchy and opposite to the principles of a republic: "When republican virtue fails, slavery ensues." 22 Though Jefferson included these thoughts in his first draft of the Declaration of Independence, delegates from slaveholding states threatened to withdraw support for separation unless Jefferson removed all references to slavery. ${ }^{23}$ Thus, the practice of slavery remained entrenched in the newly independent American nation, despite Paine's arguments in Common

\footnotetext{
${ }^{20}$ Paine, Common Sense, 16.

21 "Founding Father Thomas Paine: He Genuinely Abhorred Slavery." Journal of Blacks in Higher Education, (2005).

${ }^{22}$ Paine, Common Sense, 11.

${ }^{23}$ Philip Detweiler, "Congressional Debate on Slavery and the Declaration of Independence." The American Historical Review 63, no. 3 (1958), 600-610.
} 
Sense. Additionally, Paine's suggestions on the formation of government seemed to have little influence on the political structure of the early United States. Pain proposed that the colonies be separated into eight or ten districts, and that each colony send 30 delegates to congress, for a total number of 390 representatives in congress. ${ }^{24}$ In reality, the first United States Congress comprised 26 senators and 64 representatives, totalling merely 90 delegates-much less than Paine had advocated. Paine also suggested the President be selected from a different colony each election, which the founding fathers seemed to ignore in favour of the electoral college system that lasts today. Therefore, though the influence of Paine's document is evident in certain regards, it is clearly restricted in these other social and political aspects.

Considered alongside social, economic, and political conditions before and after the American revolution, Common Sense neither presented radically new ideas, nor engendered a ubiquitous influence on the formation of the United States of America. Despite these limitations, Paine's pamphlet nevertheless achieved lasting, unprecedented repercussions through masterful writing and literary strategies. Through straightforward diction, he appealed to commoners in an accessible manner, and through relatable imagery and allusions to popular, intellectual culture, he enlisted emotional support for his ideas. Thus, Common Sense rightly endures as an instrumental and deliberately layered publication inciting the American revolution.

${ }^{24}$ Paine, Common Sense, 19. 
Bibliography

"A History of the American Theatre." American Railroad Journal, (November 1832): 714-715. http://login.ezproxy.library.ualberta.ca/login?url=http://search.ebscohost.com/login.aspx? direct $=$ true $\& d b=\operatorname{tpp} \& A N=44986550 \&$ site $=$ eds-live $\&$ scope $=$ site.

Detweiler, Philip F. "Congressional Debate on Slavery and the Declaration of Independence." The American Historical Review 63, no. 3, (1958): 598-616. http://login.ezproxy.library.ualberta.ca/login?url=http://search.ebscohost.com/login.aspx? direct=true $\& d b=e d s j s r \& A N=e d s j s r .10 .2307 .1848882 \&$ site=eds-live $\&$ scope $=$ site.

Paine, Thomas. Common Sense. London: Printed for H.G. Symonds, 1792. http://login.ezproxy.library.ualberta.ca/login?url=http://search.ebscohost.com/login.aspx? direct $=$ true $\& \mathrm{db}=$ cat03710a $\& \mathrm{AN}=$ alb.3426029 $\&$ site $=$ eds-live $\&$ scope $=$ site.

"Founding Father Thomas Paine: He Genuinely Abhorred Slavery." Journal of Blacks in Higher Education, (2005): 45. https://www.jstor.org.login.ezproxy.library.ualberta.ca/stable/25073236.

Greene, Jack P. “An Uneasy Connection: An Analysis of the Preconditions of the American Revolution." Essays on the American Revolution, edited by Stephen G. Kurtz and James H. Hutson, 32-80. University of North Carolina Press, 1973.

Holmes, John R. "Paine Publishes Common Sense." Salem Press Encyclopedia, 2013. http://login.ezproxy.library.ualberta.ca/login?url=http://search.ebscohost.com/login.aspx? direct $=$ true $\& \mathrm{db}=\mathrm{ers} \& \mathrm{AN}=89158750 \&$ site $=$ eds-live $\&$ scope $=$ site.

Jefferson, Thomas. The Political Writings of Thomas Jefferson. Edited by Merril D. Peterson. Thomas Jefferson Memorial Foundation, 1993. http://katalog.nukat.edu.pl/lib/item?id=chamo:878145\&theme=nukat . 
Larkin, Edward. Thomas Paine and the Literature of Revolution. Cambridge University Press, 2005.

http://login.ezproxy.library.ualberta.ca/login?url=http://search.ebscohost.com/login.aspx? direct $=$ true $\& d b=c a t 03710 a \& A N=a l b .7561147 \&$ site $=$ eds-live $\&$ scope $=$ site. 